\section{Response to: 'In search for the ideal anatomical composition of vascularised human skin equivalents for systemic sclerosis translational research: should we recruit the telocytes?' by Manetti and Matucci-Cerinic}

We would like to thank Dr Manetti and Prof Matucci-Cerinic ${ }^{1}$ for their stimulating letter on our manuscript. ${ }^{2}$ The authors discuss strengths and potential limitations of vascularised skin equivalents as a novel in vitro model for systemic sclerosis (SSc).

They raise two key points:

1. Although the model includes key populations of cells relevant to skin homeostasis and to the pathogenesis of SSc such as fibroblasts, endothelial cells and keratinocytes, other relevant cell populations are not included. Can the model be modified to include less frequent, but also potentially relevant cellular populations?

2. Do vascularised skin equivalents in their current form address fibroblast heterogeneity in the skin?

(Ad 1) We fully agree that vascularised human skin equivalents, although more complex than many other in vitro models and more physiological, remain a model system and thus a simplification of human skin. For practical reasons, this simplification included a restriction to the most abundant resident cell types in human skin and omittance of other less abundant cell types. However, addition of other resident cell populations of interest such as melanocytes or telocytes would require only minor modifications of the current protocol. Whether those cells are able to home to their physiological niches in the skin (eg, melanocytes at the epidermal-dermal interface) will require further studies. Although not in the focus of this publication, the functional vascular system in combination with the perfusion system enables studies on interactions of defined circulating leucocyte populations with resident skin cells. A first manuscript describing the changes in vascularised skin equivalents induced by addition of mismatched leucocytes into the perfusion system is currently in preparation by our coauthors Groeber et al. Moreover, we are currently working on protocols to include tissue resident leucocyte populations such as Langerhans cells into the vascularised skin equivalents.

(Ad 2) We fully agree that fibroblast heterogeneity is an important area that deserves more attention and further studies, especially in the context of SSc. Evidence from various different studies indicates that individual fibroblast subpopulations tend to lose specific surface markers and change the transcriptional profile rather rapidly under standard 2D culture conditions in vitro. However, Philippeos and coworkers demonstrated that this phenotype switch may be only transient and that fibroblasts may maintain a functional memory. When cultured fibroblasts isolated from the reticular and the papillary dermis were reseeded in their physiological 3D environment (in this case decellularised dermal matrices), they reacquired differences in morphology and functionality, with distinct activation in key signalling pathways such as WNT signalling. ${ }^{3}$ The local niche may shape or at least unmask the specific phenotype of fibroblast subpopulations. This raises the possibility that ostensibly homogenous cultured fibroblasts reclaim their specific phenotypes and functions in the 3D microenvironment of the vascularised skin equivalent. However, further studies are required to confirm this assumption and to analyse whether the findings on reticular and papillary fibroblasts can be extended to other subpopulations as well.

\section{Alexandru Emil Matei $\odot$, Jörg H W Distler $\odot$}

Department of Internal Medicine III, University of Erlangen, Erlangen, Germany

Correspondence to Dr Jörg H W Distler, Department of Internal Medicine III, University of Erlangen, Erlangen 91054, Germany; joerg.distler@uk-erlangen.de

Handling editor Josef 5 Smolen

Competing interests None declared.

Patient consent for publication Not required.

Provenance and peer review Commissioned; internally peer reviewed.

(c) Author(s) (or their employer(s)) 2021. No commercial re-use. See rights and permissions. Published by BMJ.

\section{Check for updates}

To cite Matei AE, Distler JHW. Ann Rheum Dis 2021;80:e150.

Received 2 October 2019

Revised 4 October 2019

Accepted 8 October 2019

Published Online First 15 October 2019

\section{Linked}

- http://dx.doi.org/10.1136/annrheumdis-2019-216371

Ann Rheum Dis 2021;80:e150. doi:10.1136/annrheumdis-2019-216393

\section{ORCID iDs}

Alexandru Emil Matei http://orcid.org/0000-0003-1248-3145

Jörg H W Distler http://orcid.org/0000-0001-7408-9333

\section{REFERENCES}

1 Manetti M, Matucci-Cerinic M. In search for the ideal anatomical composition of vascularised human skin equivalents for systemic sclerosis translational research: should we recruit the telocytes? Ann Rheum Dis 2019. doi:10.1136/ annrheumdis-2019-216371. [Epub ahead of print: 3 Oct 2019].

2 Matei A-E, Chen C-W, Kiesewetter L, et al. Vascularised human skin equivalents as a novel in vitro model of skin fibrosis and platform for testing of antifibrotic drugs. Ann Rheum Dis 2019. doi:10.1136/annrheumdis-2019-216108. [Epub ahead of print: 20 Sep 2019].

3 Philippeos C, Telerman SB, Oulès B, et al. Spatial and single-cell transcriptional profiling identifies functionally distinct human dermal fibroblast subpopulations. I Invest Dermatol 2018;138:811-25. 